[Postprint de: Pérez, L.I.; Gundel, P.E.; Zabalgogeazcoa, I.; Omacini, M. 2020. An ecological framework for understanding the roles of Epichloë endophytes on plant defenses against fungal diseases. Fungal Biology Reviews, 34: 115-125. https://creativecommons.org/licenses/by-nc-nd/4.0/]

\title{
An ecological framework for understanding the roles of Epichloë endophytes on plant defenses against fungal diseases
}

\author{
Luis I. Pérez1, Pedro E. Gundel ${ }^{1}$, Iñigo Zabalgogeazcoa ${ }^{2}$ and Marina Omacini ${ }^{1}$ \\ 1 IFEVA (CONICET - Facultad de Agronomía, Universidad de Buenos Aires), Av. San Martín 4453 \\ (C1417DSE) Buenos Aires, Argentina \\ 2 Department of Abiotic Stress, Instituto de Recursos Naturales y Agrobiología de Salamanca (IRNASA) \\ Consejo Superior de Investigaciones Científicas (CSIC) Salamanca, España
}

\section{Keywords}

ENDOPHYTE, PATHOGEN, MUTUALISM, SYMBIOSIS, DISEASE ECOLOGY, META-ANALYSIS

\begin{abstract}
Plants harbor a wide diversity of microorganisms in their tissues. Some of them have a long co-evolutionary history with their hosts, likely playing a pivotal role in regulating the plant interaction with other microbes such as pathogens. Some cool-season grasses are symbiotic with Epichloë fungal endophytes that grow symptomless and systemically in aboveground tissues. Among the many benefits that have been ascribed to endophytes, their role in mediating plant interactions with pathogens has been scarcely developed. Here, we explored the effects of Epichloë fungal endophytes on the interaction of host grasses with fungal pathogens. We made a meta-analysis that covered a total of 18 host grass species, 11 fungal endophyte species, and 22 fungal pathogen species. We observed endophyte-mediated negative effects on pathogens in vitro and in planta. Endophyte negative effects on pathogens were apparent not only in laboratory but also in greenhouse and field experiments. Epichloë fungal endophytes had negative effects on pathogen growth and conidial germination. On living plants, endophytes reduced both severity and incidence of the disease as well as colonization and subsequent infection of seeds. Symbiosis with endophytes showed an inhibitory effect on debilitator and killer pathogens, but not on
\end{abstract}


castrators, and this effect did not differ among biotrophic or necrotrophic lifestyles. We found that this protection can be direct through the production of fungistatic compounds or induction of plant defenses, and indirect associated with endophytegenerated changes in the abiotic or the biotic environment. Several mechanisms operate simultaneously and contribute differentially to the reduction of disease within grass populations. 


\section{Introduction}

\subsection{The symbiotic plant as a holobiont: Identifying roles within plant microbial community}

Within the complex plant microbiota (see glossary), some organisms can be readily labeled as beneficial or detrimental according to their main effect on host plants, but for the majority, their functional roles remain uncertain (Martin et al. 2017; Newton et al. 2010; Peiffer et al. 2013). Depending on the duration of the association, microbial symbionts can be persistent, lasting for the entire life cycle of their hosts or transient during certain stages, reflecting a high degree of co-evolutionary integration (Sachs 2013). Some microbial symbionts are acquired via horizontal infections, while others are conserved in maternal lineages through vertical transmission to the progeny (Bright and Bulgheresi 2010; Gundel et al. 2011a). The benefits that each partner obtains from the association, and the degree of mutual integration, are important to understand the mechanisms underlying a symbiotic interaction (Kiers and West 2015). The effect a symbiont has on the outcome of the interaction of its host plant with a given pathogen will depend on the life-history traits of both microorganisms Therefore, it can be expected that beneficial symbionts with a long co-evolutionary history with their host plant species will play a pivotal role in regulating the plant interaction with other microorganisms such as pathogens (May and Nelson 2014). Here, we explored the effects of the vertically transmitted Epichloë fungal endophytes on the interaction of host grasses with fungal pathogens. Since microbes are a rich source of new functional phenotypic traits for plants (Mousa and Raizada 2013), the study and conceptualization of their interactions with threats imposed by fungal pathogens open the possibility to develop new

environment-friendly strategies for agricultural sustainability (Gundel et al. 2013; Kauppinen et al. 2016b; Wei and Jousset 2017). 


\subsection{Epichloë fungal endophytes of grasses}

Many cool-season grass species are symbiotic with asexual fungal endophytes of the genus Epichloë (Ascomycota, Hypocreales, Clavicipitaceae) (Leuchtmann et al. 2014) that grow symptomless and systemically in the apoplast of aboveground tissues (see glossary). These symbioses are heritable from the mother plant to offspring through vertical seed transmission, and the endophytes depend entirely on the host plant for persistence within a grass population. This type of grass-endophyte symbioses is considered a "mutualism" because the fungus increases host fitness by protecting against natural enemies (herbivores and pathogens) and increasing plant tolerance to a variety of environmental stress factors (Hamilton et al. 2012; Malinowski and Belesky 2000). All these characteristics correlate with the high endophyte infection frequencies usually observed in natural grass populations (Gibert et al. 2012; Gundel et al. 2009).

Considering that grasses and Epichloë fungi have a long co-evolutionary history, and establish persistent symbioses (Christensen et al. 2008; Schardl et al. 2008), it is expected that they will play a role in the plant interaction with other components of the fungal community, and in particular, with pathogens. However, in comparison with the large amount of information available for plant-herbivore interactions (See for example, Clay and Schardl (2002); Saikkonen et al. (2013)), much less is known about the role of fungal endophytes on the interaction of plants with pathogens. An overview of the topic indicates that many studies would support the hypothesis that endophyte symbiosis reduces plant susceptibility to pathogens, but reports of the opposite are not uncommon. This variability in the effects of fungal endophytes on 
plant-pathogen interactions may be explained by the existence of different mechanisms operating at different levels of organization, from the inhibition of the pathogen by the endophyte, to changes in host physiology or even in the interaction networks within plant communities (Bastias et al. 2017; Bultman et al. 2012; Christensen 1996; Omacini et al. 2001; White Jr and Cole 1985).

\subsection{Looking for patterns of endophyte-mediated protection against pathogens: A meta- analysis}

The aim of this article is to explore the variation in the host response to pathogens and to provide an ecological framework to improve our knowledge on the role of Epichloë endophytes in plant protection and defense. We undertook a meta-analysis and synthesized the available information from many different experiments to test the relative importance and magnitude of the effects of some characteristics of the interacting organisms and the experimental approach (Figure 1). For example: Do results depend on the functional group of pathogens that attack the host grass (debilitators/killers/castrators, see glossary), or how they invade host tissues (biotrophs/necrotrophs/hemibiotrophs, see glossary)? Do results change with the scale and experimental approach or the response variables measured (incidence/severity/seed mortality during germination/conidial germination/pathogen growth)? Meta-analysis provides a quantitative method for integrating results of studies with different species of cool-season grasses, endophytes, and fungal pathogens.

\section{Methods for the search and analysis of the published information}

We searched in SCOPUS (http://www.scopus.com) for publications containing "Epichloë OR Neotyphodium OR Acremonium" and "Pathogen OR Pathogens OR Disease OR Diseases" (Neotyphodium and Acremonium correspond to former denominations of the genus) within abstracts, keywords, or titles. We complemented the search, by inspecting the lists of 
references of the detected studies. To be included in the analysis, studies had to (1) report on the performance of pathogenic fungi on endophyte-symbiotic vs. non-symbiotic plants (i.e. incidence, disease severity, production of pathogenic spores, spore germination, etc.), and (2) report treatment mean values, variability, and number of replicates. For each case, we extracted the following variables: host plant, fungal endophyte and pathogen identity, endophyte infection frequencies of control (E-) and endophytic $(E+)$ plant populations, type of experimental approach and response variable measured (Laboratory, greenhouse, field; effect on seed germination, incidence, severity, pathogen growth, pathogens's spore germination). We only included in our analysis Epichloë species considered mutualistic by the authors of each study. We assigned each case a single identifier (Case ID) and assigned cases (one or more) to their corresponding study (Study ID). Thus, a study ID corresponded to a single published paper in our analysis. Within each paper, we considered any performance-related response variable measured for each pair of induced and control plants to be a single case (i.e., a Case ID). In most studies, more than one response variable was measured and reported. Data in figures were extracted using GetData Graph Digitizer software (https: //www.digitizeit.de).

For each case, we calculated an effect size using the standardized mean difference (SMD) metric between endophyte-symbiotic and non-symbiotic plants, and its confidence interval in the "metafor" package 1.9-8 version in r 3.2.3 (Viechtbauer 2010). The effect size was considered significant if the confidence interval did not overlap with zero (Koricheva et al. 2013). A negative effect size means that endophytes had a negative effect, reducing pathogen growth or infection development. We also estimated the level of consistency among studies by calculating between-study heterogeneity ( $\tau 2$ and associated $\mathrm{Q}$ statistics). Because $\tau 2$ is dependent on sample size, we calculated 12 values, providing a standardized estimate of total heterogeneity ranging from 0 to 1 . We used several approaches to verify that our results 
were not impacted by publication bias (Koricheva et al. 2013): (1) inspection of funnel plots, and (2) calculation of fail-safe number.

\section{Results}

Our analysis gathered data from 22 publications, covering a total of 18 host grass species, 11 fungal endophyte species, and 22 fungal pathogen species (Table 1). At a first glance, the analyses of published results revealed an overall negative effect of the endophyte (directly or indirectly) on the growth and infection of pathogens in vitro and in planta (Figure 2, Table S1). Most of these studies were conducted under laboratory conditions (53\%), the rest were reports of greenhouse $(27 \%)$ or field $(20 \%)$ experiments. Laboratory experiments showed a negative effect of endophytes on pathogen growth $(z=-5.67 ; p<0.0001$ Fig. 2$)$. This effect was also observed in greenhouse and field experiments, however the size of the effect was less significant with this increase in biotic complexity (greenhouse: $z=-4.96 ; p<0.0001$; Field: $z=-1.98 ; p=0.04 ; Q M_{(d f ~ 3)}=47.05, p<0.0001 ;$ Fig. 2).

The effect of endophytes on pathogens differed according to the response variable estimated in the study $(\mathrm{QM}(\mathrm{df}=5)=35.90, \mathrm{p}<0.0001)$. The in vitro laboratory experiments showed $\mathrm{a}$ marginal negative effect of endophytes on pathogen growth, and a significant inhibition of conidial germination $(Z=-2.92, p=0.0035$, and $Z=-4.63, p<0.0001$; Fig.2). The presence of endophytes inside host seeds also reduced pathogen colonization and subsequent infection ( $Z$ $=-2.99, p=0.0027 ;$ Fig 3$)$. Regarding experiments with living plants performed in greenhouse and field conditions, our analysis revealed that endophytes reduced both the severity and the incidence of the disease (severity: $Z=-2.76, p=0.0057$; incidence: $Z=-4.54, p<0.0001$; Fig 2). This negative effect differed among annual and perennial grasses, being significant only in the latter $\left(Q M_{\text {(df 2) }}=21.87, p<0.0001\right.$; Annual: $Z=-1.46, p=0.1439$; Perennial: $Z=-4.51, p<$ 0.0001; Fig 3). 
Regarding the characteristics of pathogens, the analysis of pathogen functional groups (Thrall et al. 2007) and their use of resources provided valuable information. Symbiosis with endophytes had different effects on the pathogens depending on their classification.

Debilitator (73.5\% of the observations) and killer (19\%) pathogens were significantly inhibited by endophytes (debilitators: $Z=-4.28, p<0.0001$; killer: $Z=-4.27, p<0.0001$ ) while castrators $(7.5 \%)$ were not $(Z=-1.70, p=0.088)\left(Q M_{(d f 3)}=26.71, p<0.0001\right.$, Fig. 4). The endophyte effect did not differ between biotrophic or necrotrophic pathogens (biotrophic: $Z$ = -2.93, $\mathrm{p}=0.0034$; necrotrophic: $\mathrm{Z}=-5.17, \mathrm{p}<0.0001 ; \mathrm{Q} \mathrm{M}_{(\mathrm{df} 3)}=40.61, \mathrm{p}-\mathrm{val}<0.0001 ;$ Fig. 4). Hemibiotrophic pathogens, however, showed inconclusive results, maybe associated with the low number of studies.

\section{Discussion}

\subsection{Disentangling the multiple effects of Epichloë endophyte on plant fungal pathogens} Our results show that symbiosis with endophytes has a negative overall effect on infection by pathogens. The heterogeneity associated with the scale and type of experiment is perhaps one of the most interesting results of this analysis, and highlights the effect of the environmental conditions on the interaction as well as the low degree of correspondence between laboratory and field studies, where more variable results were observed (Fig. 3)(Cook and Baker 1983). This increase in complexity in the field gives us a greater likelihood of having more realistic observations, but at the expense of accuracy in the results. Besides, it is important to note that laboratory tests could have a bias towards pathogens that can be cultured in vitro, excluding many biotrophic pathogens such as rusts and powdery mildews (Farr et al. 1989).

Among the experiments performed under controlled conditions (Fig.2), seed germination assays were more conclusive and less variable than other ecological experiments. Conidial 
germination experiments performed in vitro were consistent with seed germination assays suggesting that some of the mechanisms observed in vitro could be responsible for the patterns observed in field and greenhouse experiments (Kaur et al. 2009). However, it is not known whether this effect is produced by the endophyte itself, or by changes induced by the endophyte during seed germination ( $\mathrm{Ma}$ et al. 2014). The concentration of fungal alkaloids in symbiotic seeds is high, and over $20 \%$ leaches into the medium during the imbibition phase of the germination process (Justus et al. 1997). It has been suggested that these alkaloids could have a positive effect by preventing host plants from being infected by pathogenic fungi, but at the same time, it could be negative if it inhibits mutualistic symbionts such as mycorrhiza (Mack and Rudgers 2008; Novas et al. 2011; Omacini et al. 2006). Additionally, there are other secondary compounds with antimicrobial properties (Vázquez-De-Aldana et al. 2011) produced by the endophyte that may affect the host interaction with other organisms (e.g. phenolics) (Hamilton et al. 2012; Rasmussen et al. 2007). Such signals emitted by roots are often essential for the germination of spores of root-inhabitants (Graham et al. 1982).

Although the number of trials and experimental approaches analyzed for each functional group of pathogens is not even, our results indicate that there are significant differences among groups. Endophytes had ambiguous effects on castrator pathogens. We would have expected a negative effect on these pathogens based on the close phylogenetic relationship that some castrator pathogen species, such as Claviceps purpurea, have with Epichlö̈ endophytes (Sung et al. 2007). Both endophytes and castrator pathogens compete for the ovary since the former depends exclusively on seeds for transmission to the next generation of plants. Therefore, the outcome of the interaction between both types of fungi in the ovary would be critical in ensuring their persistence within host populations (Pérez et al. 2013). However, the transmission of many castrator pathogens involves insects. Several recent studies show novel indirect ecological mechanisms by which endophytes can defend host 
grasses against diseases through negative interactions with pathogen vectors (Pérez et al. 2017; Rúa et al. 2013). Rúa et al. (2013) showed that the protective effect of symbiosis on virus infection occurs in the presence of aphids that act as virus vectors and are sensitive to the presence of the endophyte in the plant. Endophyte induced changes in volatile organic compound (VOC) emissions were recently observed in different grass species (García Parisi et al. 2014b; Li et al. 2014; Perez et al. 2017). It can be expected that a deterrent effect of endophytes on pathogen vectors through the emission of VOCs will impact negatively on the host grass interaction with pathogens. The increasing heterogeneity observed when we move upwards in biotic complexity could be associated with the different plant-endophytepathogen systems evaluated in each study, and the inclusion (or exclusion) of other members of the community that could be acting as pathogen vectors (e.g. arthropods). However, the low number of published works addressing this complexity did not allow greater exploration and understanding of this system.

\subsection{A framework for understanding the tripartite interaction among grasses, endophytes, and fungal pathogens}

In the light of our results, we propose two main mechanisms by which symbiosis with endophytes could reduce pathogen infection (Fig. 4). On the one hand, we refer to direct pathways mediated by (i) the production of fungistatic compounds (interference competition), (ii) the competition for common resources (exploitation competition) (Wehner et al. 2010) and/or (iii) the induction of plant defenses, and indirect (or ecological) pathways associated with endophyte-generated changes in either the abiotic or the biotic host environment, that could ultimately have an impact on the pathogen's ecology (Pérez et al. 2013; Pérez et al. 2017; Rúa et al. 2013). 


\section{1.a Direct effects: Endophyte-pathogen interaction and elicitation of host defenses}

Epichloë endophytes live within aboveground tissues of host grasses. Their distribution and density can change through the life cycle of the host plant, colonizing new tissues as the plant advances in its ontogeny. Considering this, it could be expected that the impact of the symbiosis on the development of diseases may depend first on the type of tissue that the pathogen infects, and second on the ontogenic stage of the host plant (Burdon 1993; Dobson and Crawley 1994). At the same time, although the endophyte colonizes only some aerial tissues of the plant, some of the antimicrobial compounds released to the apoplast can potentially be distributed systemically throughout the plant (Clarke et al. 2006; Song et al. 2015; Tian et al. 2017). For example, fungistatic compounds such as the Efe-AfpA protein, isolated from the apoplast of symbiotic Festuca rubra plants, reduced significantly the growth in vitro of the pathogenic fungus Sclerotinia homoeocarpa e (Tian et al. 2017).

The success of the symbiosis on a host grass population depends on the number of new symbiotic individuals in the next generation (Gundel et al. 2009; Gundel et al. 2010; Gundel et al. 2011b). From this point of view, different types of response could be expected depending on whether the pathogen is debilitating, killing, or castrating the host plant (Burdon 1993; Dobson and Crawley 1994). For example, a debilitator pathogen that causes reductions in the photosynthetic rate might compete for photosynthates with an endophyte. Depending on the result of this competition, a reduction in endophyte transmission to the next generation could be expected, as observed in the interaction with some herbivores, where grazing caused a five-fold decrease in seed transmission in symbiotic Lolium multiflorum populations. (García Parisi et al. 2012). On the other hand, a killer pathogen kills its host for saprophytic consumption, thereof directly removing the source of propagules for the endophyte. Finally, castrators reduce host fertility and the number of possible propagules for endophytes in the same way a granívore does (Barger and Tannenbaum 1998; Knoch et al. 
1993). However, some of these aspects are generally not considered when assessing the effect of symbiosis on the process of pathogen infection.

Plant defenses are the first shield a pathogen must overcome once it has arrived at a potential host. Recent studies suggest that endophytes may interfere with plant physiological responses to biotrophic pathogen infections (see Bastias et al. 2017). As the downregulation of the salicylic acid (SA) signaling pathway would be essential to maintain the symbiotic relationship with beneficial microorganisms, it could be detrimental to host performance by allowing herbivory by sucking insects and infection by biotrophic pathogens. In the case of herbivores, the reduction of the expression of SA-associated defenses is compensated by the synthesis of fungal alkaloids that keep herbivory rates even lower than those achieved by SA. The effects of fungal alkaloids on herbivory rates have been extensively described; however, not much is known about their effect on pathogen growth and the prevention of pathogen infection. The jasmonic acid (JA) pathway, as the main response to attack by chewing herbivores and necrotrophic pathogens, has been shown not to affect the persistence of the association with symbiotic microorganisms (Bastias et al. 2017). Furthermore, in plants associated with endophytes producing alkaloids with no effectivity against chewing herbivores, the performance of these consumers was significantly reduced suggesting that the JA pathway is enhanced in symbiotic plants (Bastias et al. 2017)

\section{2.b Indirect effects: Endophytes modulate host environment and reduce disease incidence}

Fungi from the family Clavicipitaceae have a long coevolutionary history with insects (Humber 2008; Sung et al. 2007; Sung et al. 2008). While some Cordyceps species are entomopathogens of a wide variety of arthropods, Claviceps and sexually reproduced Epichloë fungal species rely on insects to disperse spores from plant to plant. Thus, considering that some Epichlö̈ species have lost their pathogenicity to turn into mutualistic fungal endophytes (Selosse and Schardl 2007), some preexisting fungus-mediated mechanisms may have changed to play a 
new functional role in the new interaction. For example, specific VOCs playing a role in attracting Botanophila flies, an insect involved in the dispersion of gametes among stromata (Steinebrunner et al. 2008), may have remained conserved and even gained new functionality in plant-insect interactions. This idea has been partially addressed, and studies have shown that the association of plants with endophytes reduced the visit rate by arthropods - potential vectors of pathogens - consequently reducing the infection level (Pérez et al. 2017; Rúa et al. 2013). Additionally, there is evidence suggesting that leaf endophytes might affect root interactions with soil microorganisms, specifically reducing the growth of pathogens and disease development (García Parisi et al. 2014a; Guo et al. 2015 ; Pérez et al. 2016). These changes in the rhizosphere may be related to the differential profiles of root exudates in endophyte-symbiotic and non-symbiotic plants (Matthews and Clay 2001; Omacini et al. 2012), that can stimulate rhizospheric microbial activity and promote "microbial mining" for nutrients (Verma and White 2019; White et al. 2015). Endophyte-mediated increased diversity of beneficial microorganisms in the rhizosphere could also contribute to the development of suppressive soils, hindering the development of pathogenic microorganisms and the subsequent infection of host plants. These indirect mechanisms remained unnoticed in studies of endophyte-conferred protection against pathogens. However, more integrated approaches are needed to unveil the importance of biotic complexity on the outcomes of plant-endophyte interactions in the presence of plant pathogens.

\section{Concluding remarks and future perspectives}

Among the reports used for this analysis, there was large heterogeneity associated with factors such as the functional group of pathogens and the type of experimental approaches used. Despite this, the meta-analysis of the published literature on the tripartite interaction between grasses, endophytes, and pathogens revealed a robust symbiosis effect, reducing 
pathogen infection in host plants. Our understanding of tripartite interactions between plants, endophytes, and pathogens is still in an early stage and new studies are needed to address some of the questions that have emerged from this analysis. However, here we propose several mechanisms that operate individually, or even simultaneously, and contribute differentially to the reduction of diseases within grass populations.

Mounting evidence supports the ubiquity of symbiotic microorganisms and their roles in plant adaptation to the abiotic and abiotic environment (Martin, 2017; Newton et al.2010; Rosenberg and Zilber-Rosenberg, 2014). However, our understanding of the microorganisms' roles on host performance is hindered by the experimental difficulty of manipulating more than one symbiotic microorganism at once (Afkhami et al. 2020). The Epichloë fungal endophytes of grasses offer a unique opportunity to manipulate the symbiotic status of plants and control the presence/absence of other beneficial or harmful microorganisms (Kauppinen et al. 2016a). With a focus on fungal pathogens, here we found strong support for an endophyte-mediated resistance of plants to diseases. Most interesting, our work identified new ecological pathways by which the presence of fungal endophytes can reduce the incidence of fungal pathogens in grass populations. However, we also identified constraints to our full comprehension of the tripartite interaction among plants, endophytes, and fungal pathogens. The main obstacles are to scale up results from in vitro to in vivo studies as well as results from lab-based in planta experiments to field-based experiments. Therefore, new research directions should consider not only the three main players (i.e. the plant, the Epichlö̈, and a pathogen), but also other organisms in the biotic community such as herbivores, pollinators, soil microorganisms, and other plants. We hope our work sparks new studies on the endophyte-mediated plant-pathogen interaction under ecological settings.

\section{Acknowledgments}


We thank the editor and three anonymous reviewers for the comments that significantly improved the quality of this manuscript. This work was funded by the University of Buenos Aires (UBA), the National Research Council (CONICET), and the National Scientific and Technological Promotion (FONCYT). Secretaria de Ciencia y Técnica, Universidad de Buenos Aires (PICT 2633-2016).

\section{References}

Afkhami ME, Almeida BK, Hernandez DJ, Kiesewetter KN, Revillini DP (2020) Tripartite mutualisms as models for understanding plant-microbial interactions. Current Opinion in Plant Biology 56:28-36

Barger JL, Tannenbaum MG (1998) Consumption of endophyte-infected fescue seeds and osmoregulation in white-footed mice. Journal of Mammalogy 79:464-474

Bastias DA, Martínez-Ghersa MA, Ballaré CL, Gundel PE (2017) Epichloë Fungal Endophytes and Plant Defenses: Not Just Alkaloids. Trends in Plant Science 22:939-948 doi:https://doi.org/10.1016/j.tplants.2017.08.005

Bright M, Bulgheresi S (2010) A complex journey: transmission of microbial symbionts. Nature reviews Microbiology 8:218-230 doi:10.1038/nrmicro2262

Bultman TL, Aguilera A, Sullivan TJ (2012) Influence of fungal isolates infecting tall fescue on multitrophic interactions. Fungal Ecology 5:372-378

Burdon JJ (1993) The Structure of Pathogen Populations in Natural Plant Communities. Annual Review of Phytopathology 31:305-323 doi:doi:10.1146/annurev.py.31.090193.001513

Clarke BB, White Jr JF, Hurley RH, Torres MS, Sun S, Huff DR (2006) Endophyte-mediated suppression of dollar spot disease in fine fescues. Plant Disease 90:994-998

Clay K, Schardl C (2002) Evolutionary origins and ecological consequences of endophyte symbiosis with grasses. American Naturalist 160:S99-S127

Cook RJ, Baker KF (1983) The Nature and Practice of Biological Control of Plant Pathogens. American Phytopathological Society, St Paul, MN.

Christensen MJ (1996) Antifungal activity in grasses infected with Acremonium and Epichloë endophytes Australasian Plant Pathology 25:186-191

Christensen MJ et al. (2008) Epichloë endophytes grow by intercalary hyphal extension in elongating grass leaves. Fungal genetics and biology : FG \& B 45:84-93

Dobson A, Crawley M (1994) Pathogens and the structure of plant communities. Trends in Ecology and Evolution 9:393-397

Farr DF, Bills GF, Chamuris GP, Rossman AY (1989) Fungi on plants and plant products in the United States. APS Press, St. Paul, Minnesota

García Parisi P, Lattanzi F, Grimoldi A, Omacini M (2014a) Multi-symbiotic systems: functional implications of the coexistence of grass-endophyte and legume-rhizobia symbioses. Oikos doi:10.1111/oik.01540

García Parisi PA, Casas C, Gundel PE, Omacini M (2012) Consequences of grazing on the vertical transmission of a fungal Neotyphodium symbiont in an annual grass population. Austral Ecology 37:620-628 
García Parisi PA, Grimoldi AA, Omacini M (2014b) Endophytic fungi of grasses protect other plants from aphid herbivory. Fungal Ecology 9:61-64 doi:http://dx.doi.org/10.1016/j.funeco.2014.01.004

Gibert A, Volaire F, Barre P, Hazard L (2012) A fungal endophyte reinforces population adaptive differentiation in its host grass species. New Phytologist 194:561-571

Graham JH, Leonard RT, Menge JA (1982) Interaction of light-intensity and soil-temperature with phosphorus inhibition of vesicular arbuscular mycorrhiza formation. New Phytologist 91:683-690 doi:10.1111/j.1469-8137.1982.tb03347.x

Gundel P, Garibaldi L, Helander M, Saikkonen K (2013) Symbiotic interactions as drivers of trade-offs in plants: effects of fungal endophytes on tall fescue. Fungal Diversity 60:514 doi:10.1007/s13225-013-0224-y

Gundel PE, Garibaldi LA, Martínez-Ghersa MA, Ghersa CM (2011a) Neotyphodium endophyte transmission to Lolium multiflorum seeds depends on the host plant fitness. Environmental and Experimental Botany 71:359-366

Gundel PE, Garibaldi LA, Tognetti PM, Aragón R, Ghersa CM, Omacini M (2009) Imperfect vertical transmission of the endophyte neotyphodium in exotic grasses in grasslands of the flooding pamp.a Microbial Ecology 57:740-748

Gundel PE, Martínez-Ghersa MA, Batista WB, Ghersa CM (2010) Dynamics of Neotyphodium endophyte infection in ageing seed pools: Incidence of differential viability loss of endophyte, infected seed and non-infected seed. Annals of Applied Biology 156:199209

Gundel PE, Rudgers JA, Ghersa CM (2011b) Incorporating the process of vertical transmission into understanding of host-symbiont dynamics. Oikos 120:1121-1128

Guo J, McCulley RL and McNear DH Jr. (2015) Tall fescue cultivar and fungal endophyte combinations influence plant growth and root exudate composition. Frontiers in Plant Science 6:183.

Hamilton CE, Gundel PE, Helander M, Saikkonen K (2012) Endophytic mediation of reactive oxygen species and antioxidant activity in plants: A review. Fungal Diversity 54:1-10

Humber RA (2008) Evolution of entomopathogenicity in fungi. Journal of Invertebrate Pathology 98:262-266 doi:10.1016/j.jip.2008.02.017

Justus M, Witte L, Hartmann T (1997) Levels and tissue distribution of loline alkaloids in endophyte-infected Festuca pratensis. Phytochemistry 44:51-57

Kauppinen M, Saikkonen K, Helander M, Pirttilä AM, Wäli PR (2016a) Epichloë grass endophytes in sustainable agriculture. Nature Plants 2:1-7

Kauppinen M, Saikkonen K, Helander M, Pirttilä AM, Wäli PR (2016b) Epichloë grass endophytes in sustainable agriculture. Nature Plants 2:15224 doi:10.1038/nplants.2015.224

Kaur H, Kaur R, Kaur S, Baldwin IT, Inderjit (2009) Taking ecological function seriously: Soil microbial communities can obviate allelopathic effects of released metabolites. PLoS ONE 4

Kiers ET, West SA (2015) Evolving new organisms via symbiosis. Science 348:392-394 doi:10.1126/science.aaa9605

Knoch TR, Faeth SH, Arnott DL (1993) Endophytic fungi alter foraging and dispersal by desert seed-harvesting ants. Oecologia 95:470-473

Leuchtmann A, Bacon CW, Schardl CL, White JF, Tadych M (2014) Nomenclatural realignment of Neotyphodium species with genus Epichloë. Mycologia doi:10.3852/13-251

Li T, Blande JD, Gundel PE, Helander M, Saikkonen K (2014) Epichloë Endophytes Alter Inducible Indirect Defences in Host Grasses. PLoS ONE 9:e101331 doi:10.1371/journal.pone.0101331 
Ma M, Christensen M, Nan Z (2014) Effects of the endophyte Epichloë festucae var. lolii of perennial ryegrass (Lolium perenne) on indicators of oxidative stress from pathogenic fungi during seed germination and seedling growth. European Journal of Plant Pathology:1-13 doi:10.1007/s10658-014-0563-x

Mack KML, Rudgers JA (2008) Balancing multiple mutualists: Asymmetric interactions among plants, arbuscular mycorrhizal fungi, and fungal endophytes. Oikos 117:310-320

Malinowski DP, Belesky DP (2000) Adaptations of endophyte-infected cool-season grasses to environmental stresses: Mechanisms of drought and mineral stress tolerance. Crop Science 40:923-940

Martin FM, Uroz S, Barker DG (2017) Ancestral alliances: Plant mutualistic symbioses with fungi and bacteria. Science 356 doi:10.1126/science.aad4501

Matthews JW, Clay K (2001) Influence of fungal endophyte infection on plant-soil feedback and community interactions. Ecology 82:500-509

May G, Nelson P (2014) Defensive mutualisms: do microbial interactions within hosts drive the evolution of defensive traits? Functional Ecology 28:356-363 doi:10.1111/13652435.12166

Mousa W, Raizada M (2013) The diversity of anti-microbial secondary metabolites produced by fungal endophytes: An interdisciplinary perspective. Frontiers in Microbiology 4 doi:10.3389/fmicb.2013.00065

Newton AC, Fitt BDL, Atkins SD, Walters DR, Daniell TJ (2010) Pathogenesis, parasitism and mutualism in the trophic space of microbe-plant interactions. Trends in Microbiology 18:365-373 doi:http://dx.doi.org/10.1016/j.tim.2010.06.002

Novas MV, lannone LJ, Godeas AM, Scervino JM (2011) Evidence for leaf endophyte regulation of root symbionts: Effect of Neotyphodium endophytes on the pre-infective state of mycorrhizal fungi. Symbiosis 55:19-28

Omacini M, Chaneton EJ, Ghersa CM, Müller CB (2001) Symbiotic fungal endophytes control insect host-parasite interaction webs .Nature 409:78-81

Omacini M, Eggers T, Bonkowski M, Gange AC, Jones TH (2006) Leaf endophytes affect mycorrhizal status and growth of co-infected and neighbouring plants. Functional Ecology 20:226-232

Omacini M, Semmartin M, Pérez LI, Gundel PE (2012) Grass-endophyte symbiosis: A neglected aboveground interaction with multiple belowground consequences. Applied Soil Ecology 61:273-279

Peiffer JA et al. (2013) Diversity and heritability of the maize rhizosphere microbiome under field conditions. Proceedings of the National Academy of Sciences 110:6548-6553 doi:10.1073/pnas.1302837110

Pérez LI, Gundel PE, Ghersa CM, Omacini M (2013) Family issues: fungal endophyte protects host grass from the closely related pathogen Claviceps purpurea. Fungal Ecology 6:379-386 doi:http://dx.doi.org/10.1016/j.funeco.2013.06.006

Perez LI, Gundel PE, Marrero HJ, Arzac AG, Omacini M (2017) Symbiosis with systemic fungal endophytes promotes host escape from vector-borne disease. Oecologia 184:237-245 doi:10.1007/s00442-017-3850-3

Pérez LI, Gundel PE, Omacini M (2016) Can the defensive mutualism between grasses and fungal endophytes protect non-symbiotic neighbours from soil pathogens? Plant and Soil 405:289-298 doi:10.1007/s11104-015-2568-4

Rasmussen S et al. (2007) High nitrogen supply and carbohydrate content reduce fungal endophyte and alkaloid concentration in Lolium perenne. New Phytologist 173:787-797

Rúa MA, McCulley RL, Mitchell CE (2013) Fungal endophyte infection and host genetic background jointly modulate host response to an aphid-transmitted viral pathogen. Journal of Ecology 101:1007-1018 
Sachs JL (2013) Origins, evolution, and breakdown of bacterial symbiosis. vol 5, Second edn. Academic Press, Waltham, MA

Saikkonen K, Gundel PE, Helander M (2013) Chemical ecology mediated by fungal endophytes in grasses. Journal of Chemical Ecology 39:962-968 doi:10.1007/s10886-013-0310-3

Schardl CL, Craven KD, Speakman S, Stromberg A, Lindstrom A, Yoshida R (2008) A novel test for host-symbiont codivergence indicates ancient origin of fungal endophytes in grasses. Systematic Biology 57:483-498

Song Q-Y et al. (2015) Antifungal, phytotoxic, and cytotoxic activities of metabolites from Epichlö̈ bromicola, a fungus obtained from Elymus tangutorum grass. Journal of agricultural and food chemistry 63:8787-8792

Steinebrunner F, Schiestl FP, Leuchtmann A (2008) Variation of insect attracting odor in endophytic Epichloë fungi: Phylogenetic constrains versus host influence. Journal of Chemical Ecology 34:772-782

Sung GH, Hywel-Jones NL, Sung JM, Luangsa-ard JJ, Shrestha B, Spatafora JW (2007) Phylogenetic classification of Cordyceps and the clavicipitaceous fungi. Studies in Mycology 57:5-59

Sung GH, Poinar Jr GO, Spatafora JW (2008) The oldest fossil evidence of animal parasitism by fungi supports a Cretaceous diversification of fungal-arthropod symbioses. Molecular Phylogenetics and Evolution 49:495-502

Sung, G. H., Sung, J. M., Hywel-Jones, N. L., \& Spatafora, J. W. (2007). A multi-gene phylogeny of Clavicipitaceae (Ascomycota, Fungi): Identification of localized incongruence using a combinational bootstrap approach. Molecular phylogenetics and evolution, 44(3), 1204-1223.

Thrall PH, Hochberg ME, Burdon JJ, Bever JD (2007) Coevolution of symbiotic mutualists and parasites in a community context. Trends in Ecology and Evolution 22:120-126

Tian Z, Wang R, Ambrose KV, Clarke BB, Belanger FC (2017) The Epichloë festucae antifungal protein has activity against the plant pathogen Sclerotinia homoeocarpa, the causal agent of dollar spot disease. Scientific reports 7:1-15

Vázquez-De-Aldana BR, Romo M, García-Ciudad A, Petisco C, García-Criado B (2011) Infection with the fungal endophyte Epichloë festucae may alter the allelopathic potential of red fescue. Annals of Applied Biology 159:281-290

Verma SK, White J (2019) Seed Endophytes. Springer,

Wehner J, Antunes PM, Powell JR, Mazukatow J, Rillig MC (2010) Plant pathogen protection by arbuscular mycorrhizas: A role for fungal diversity? Pedobiologia 53:197-201

Wei Z, Jousset A (2017) Plant Breeding Goes Microbial. Trends in Plant Science 22:555-558 doi:https://doi.org/10.1016/j.tplants.2017.05.009

White JF, Chen Q, Torres MS, Mattera R, Irizarry I, Tadych M, Bergen M (2015) Collaboration between grass seedlings and rhizobacteria to scavenge organic nitrogen in soils AoB. Plants 7:plu093 doi:10.1093/aobpla/plu093

White Jr JF, Cole GT (1985) Endophyte-host associations in forage grasses. III. In vitro inhibition of fungi by Acremonium coenophialum. Mycologia 77:487-489 
Table 1. Host plant species, endophyte species and pathogen species evaluated in each study included in the Metaanalysis.

\begin{tabular}{|c|c|c|c|}
\hline Host grass species & Endophyte species & Pathogen species & Reference \\
\hline $\begin{array}{l}\text { Festuca brevipila } \\
\text { Festuca rubra } \\
\text { Festuva ovina }\end{array}$ & Epichloë festucae & Sclerotinia homoeocarpa & Clarke et al. (2006) \\
\hline $\begin{array}{l}\text { Brachypodium } \\
\text { sylvaticum }\end{array}$ & Epichloë sylvatica & $\begin{array}{l}\text { Mycosphaerella graminicola } \\
\text { Stagonospora nodorum }\end{array}$ & $\begin{array}{l}\text { Steinebrunner et al. } \\
(2008)\end{array}$ \\
\hline Festuca rubra & Epichloë festucae & & \\
\hline Lolium perenne & Epichloë sp & Claviceps purpurea & Krauss et al. (2007) \\
\hline $\begin{array}{l}\text { Achnatherum } \\
\text { inebrians }\end{array}$ & Epichloë gansuense & $\begin{array}{l}\text { Bipolaris sorokiniana } \\
\text { Blumeria graminis }\end{array}$ & Li et al. (2007) \\
\hline Lolium perenne & Epichloë festucae var. lolii & $\begin{array}{l}\text { Alternaria alternata } \\
\text { Ascochyta leptospora } \\
\text { Bipolaris sorokiniana } \\
\text { Curvularia lunata } \\
\text { Fusarium avenaceum }\end{array}$ & Ma et al. (2014) \\
\hline $\begin{array}{l}\text { Festuca longifolia } \\
\text { Festuca pulchella } \\
\text { Festuca rubra } \\
\text { Festuca valesiaca } \\
\text { Koeleria cristata } \\
\text { Lolium giganteum } \\
\text { Lolium L. spp. } \\
\text { Europeb, } \\
\text { Lolium perenne } \\
\text { Lolium pratense } \\
\end{array}$ & Epichloë festucae & Drechslera erythrospila & $\begin{array}{l}\text { Niones and Takemoto } \\
(2014)\end{array}$ \\
\hline Festuca arundinacea & Epichloë coenophiala & $\begin{array}{l}\text { Bipolaris sorokiniana } \\
\text { Drechslera sp. } \\
\text { Fusarium avenaceum }\end{array}$ & Panka (2010) \\
\hline Lolium multiflorum & Epichloë occultans & $\begin{array}{l}\text { Fusarium acuminatum } \\
\text { Fusarium graminearum } \\
\text { Fusarium oxysporum } \\
\text { Rhizoctonia solani }\end{array}$ & Pérez et al. (2016) \\
\hline Lolium multiflorum & Epichloë occultans & Claviceps purpurea & Pérez et al. (2013) \\
\hline Lolium multiflorum & Epichloë occultans & Claviceps purpurea & Perez et al. (2017) \\
\hline $\begin{array}{l}\text { Achnatherum } \\
\text { inebrians } \\
\text { Achnatherum } \\
\text { inebrians }\end{array}$ & $\begin{array}{l}\text { Epichloë amarillans } \\
\text { Epichloë chisosa }\end{array}$ & $\begin{array}{l}\text { Cladosporium cucumerium } \\
\text { Curvularia lunata } \\
\text { Phomopsis vexans } \\
\text { Fusarium oxysporum }\end{array}$ & Ren et al. (2009b) \\
\hline
\end{tabular}


Rhizoctonia solani

\begin{tabular}{|c|c|c|c|}
\hline \multirow[b]{2}{*}{ Festuca pratensis } & \\
\hline & Epichloë uncinata & Blumeria graminis & Sabzalian et al. (2012) \\
\hline \multirow[t]{4}{*}{ Lolium perenne } & Epichloë festucae var. lolii & Alternaria alternata & Tian et al. (2008) \\
\hline & & Bipolaris sorokiniana & \\
\hline & & Curvularia lunata & \\
\hline & & Fusarium avenaceum & \\
\hline Festuca rubra & Epichloë festucae & $\begin{array}{l}\text { Sclerotinia } \\
\text { homoeocarpa }\end{array}$ & Tian et al. (2017) \\
\hline \multirow[t]{2}{*}{ Bromus auleticus } & Epichloë pampeanum & Ustilago bullata & Vignale et al. (2013) \\
\hline & Epichloë tembladerae & & \\
\hline Lolium pratense & Epichloë uncinatum & Typhula ishikariensis & Wäli et al. (2006) \\
\hline \multirow[t]{2}{*}{ Leymus chinensi } & Epichloë bromicola & Bipolaris sorokiniana & Wang et al. (2016) \\
\hline & & Curvularia lunata & \\
\hline Festuca arundinacea & Epichloë coenophiala & $\begin{array}{l}\text { Puccinia graminis subsp. } \\
\text { graminicola }\end{array}$ & Welty et al. (1993) \\
\hline Lolium perenne & Epichloë festucae var. lolii & Drechslera siccans & Wiewióra et al. (2015) \\
\hline $\begin{array}{l}\text { Achnatherum } \\
\text { inebrians }\end{array}$ & Epichloë gansuensis & Blumeria graminis & Xia et al. (2016) \\
\hline $\begin{array}{l}\text { Achnatherum } \\
\text { inebrians }\end{array}$ & Epichloë gansuensis & Blumeria graminis & Xia et al. (2015) \\
\hline $\begin{array}{l}\text { Achnatherum } \\
\text { inebrians }\end{array}$ & Epichloë sp & Cladosporium sp & Xie et al. (2008) \\
\hline Festuca arundinacea & Epichloë coenophiala & Curvularia sp & \\
\hline Lolium perenne & Epichloë festucae var. lolii & Fusarium $s p$ & \\
\hline Festuca sinensis & Epichloë sp & Alternaria alternata & (Zhou et al. (2015)) \\
\hline
\end{tabular}


Figure 1. Direct and indirect mechanisms by which leaf fungal endophytes can modulate the interaction of host plants with pathogens, and the experimental approaches that are usually taken to unveil them. "Direct mechanisms" involve a direct effect of the endophyte on pathogen development/growth, including those effects mediated by induction of host plant defenses. "Indirect mechanisms" involve changes in host ecological interactions that impact on the dynamics of pathogen infection. $P$ symbolizes the pathogen propagule. VOCs symbolizes volatile organic compounds as an example of endophyte-modulated changes in host environment. Black lines represent endophytes.

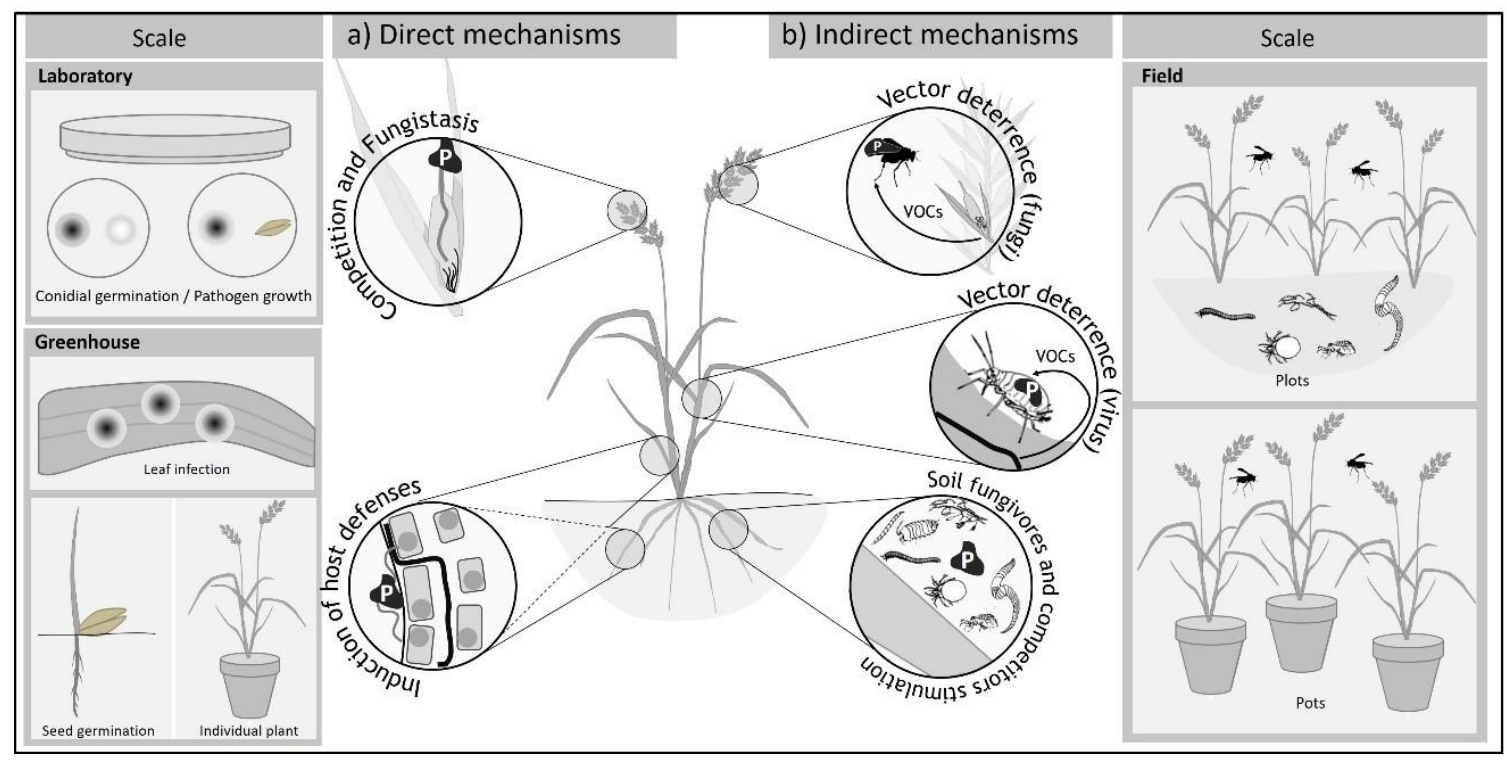


Figure 2. Estimated effect size $(S M D \pm 95 \% \mathrm{Cl})$ of the Epichloë endophyte (symbiotic vs. non-symbiotic plants) on pathogen growth and infection, according to the scale of the experiments and the response variables measured. A shift of the mean to the left means a protective role by the endophyte on the host plant in terms of disease development and pathogen growth. Numbers between brackets represent the number of observations.

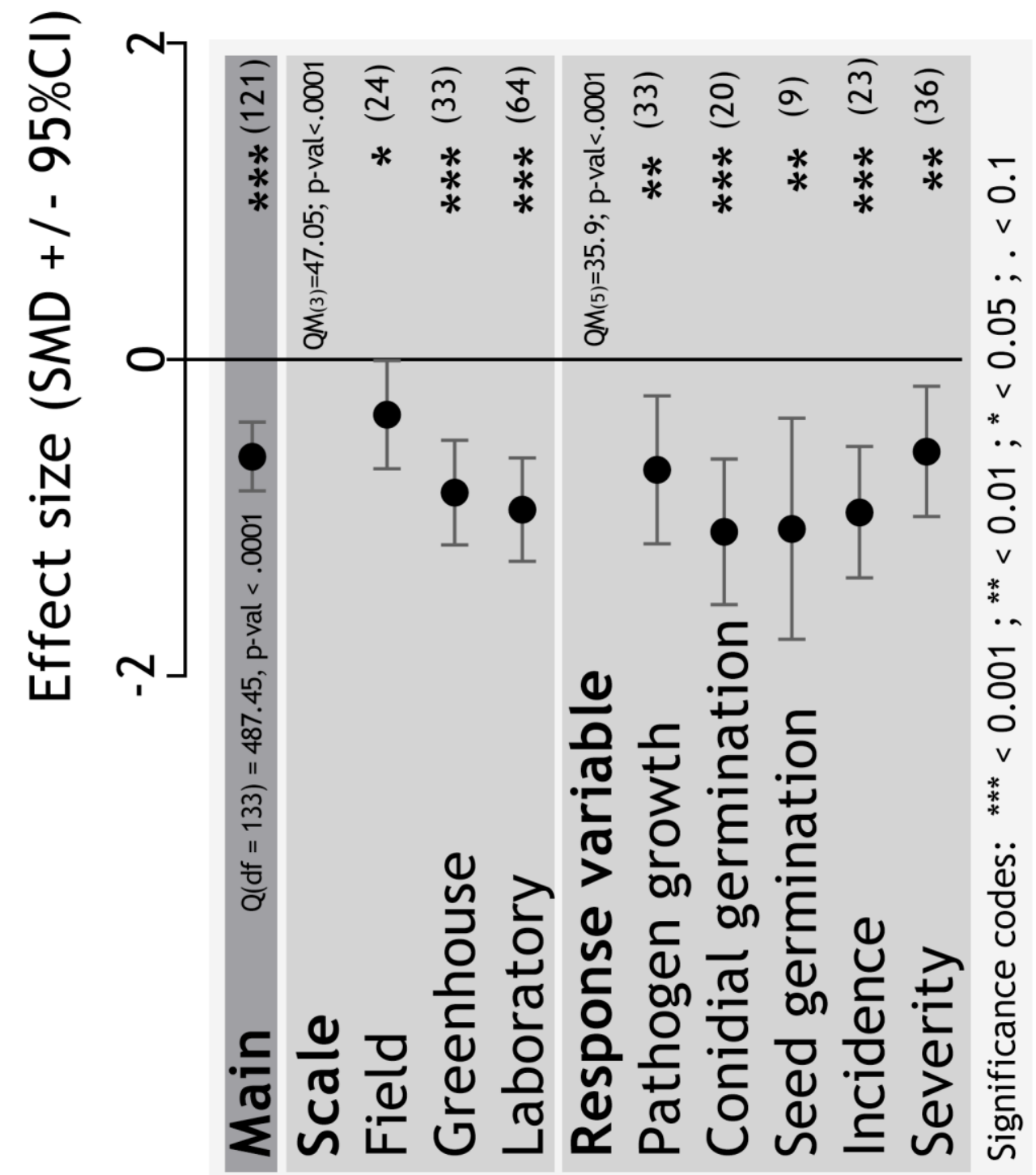


Figure 3. Estimated effect size $(\mathrm{SMD} \pm 95 \% \mathrm{Cl})$ of the Epichloë endophyte (symbiotic vs. non-symbiotic plants) on pathogen growth and infection, according to the host life cycle. A shift of the mean to the left means a protective role by the endophyte on the host plant in terms of disease development and pathogen growth. Numbers between brackets represent the number of observations.

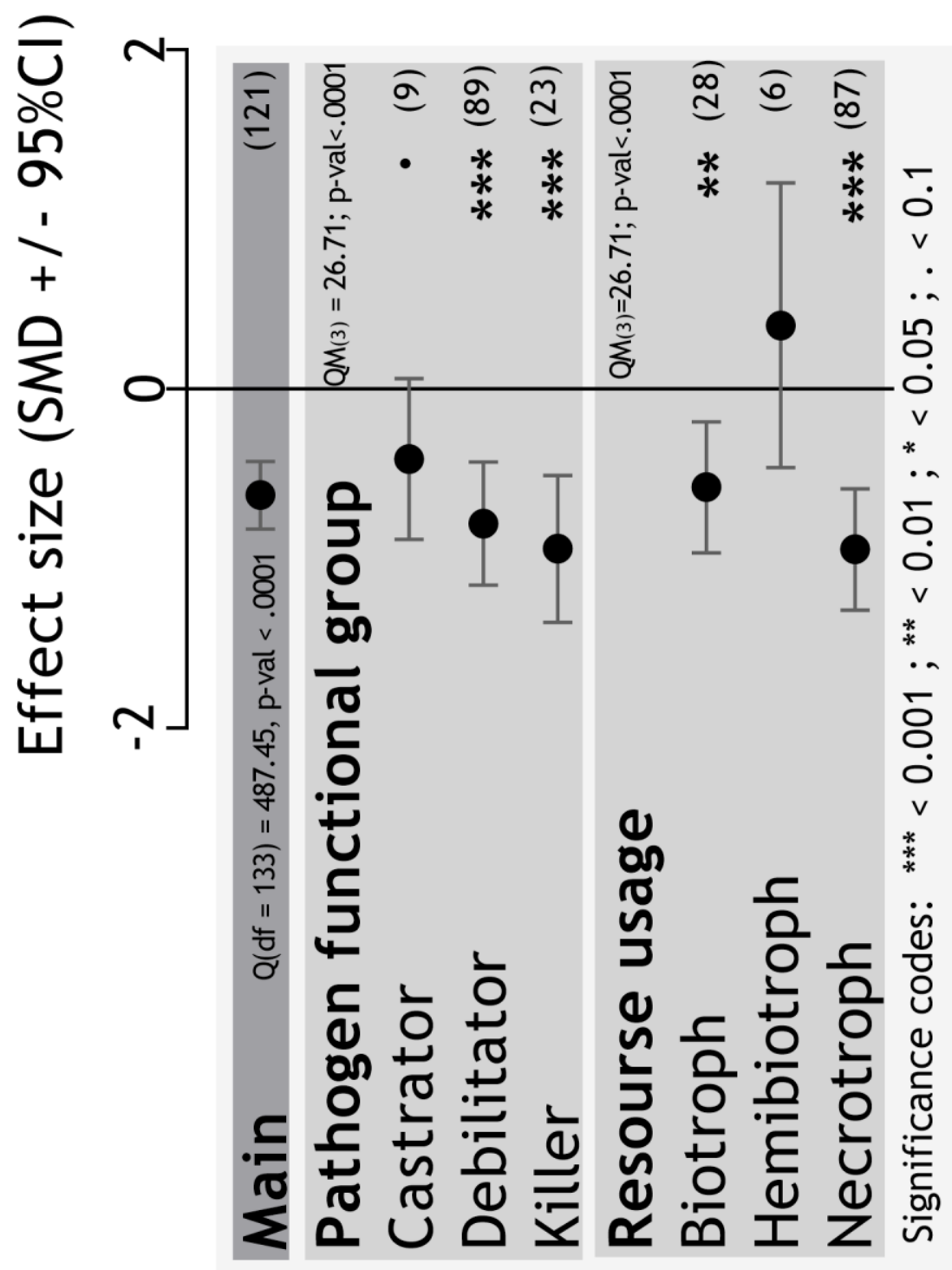


Figure 4. Estimated effect size $(S M D \pm 95 \% \mathrm{Cl})$ of the Epichloë endophyte (symbiotic vs. non-symbiotic plants) on pathogen growth and infection, according to pathogen functional group and how they invade host tissues. A shift of the mean to the left means a protective role by the endophyte on the host plant in terms of disease development and pathogen growth. Numbers between brackets represent the number of observations.

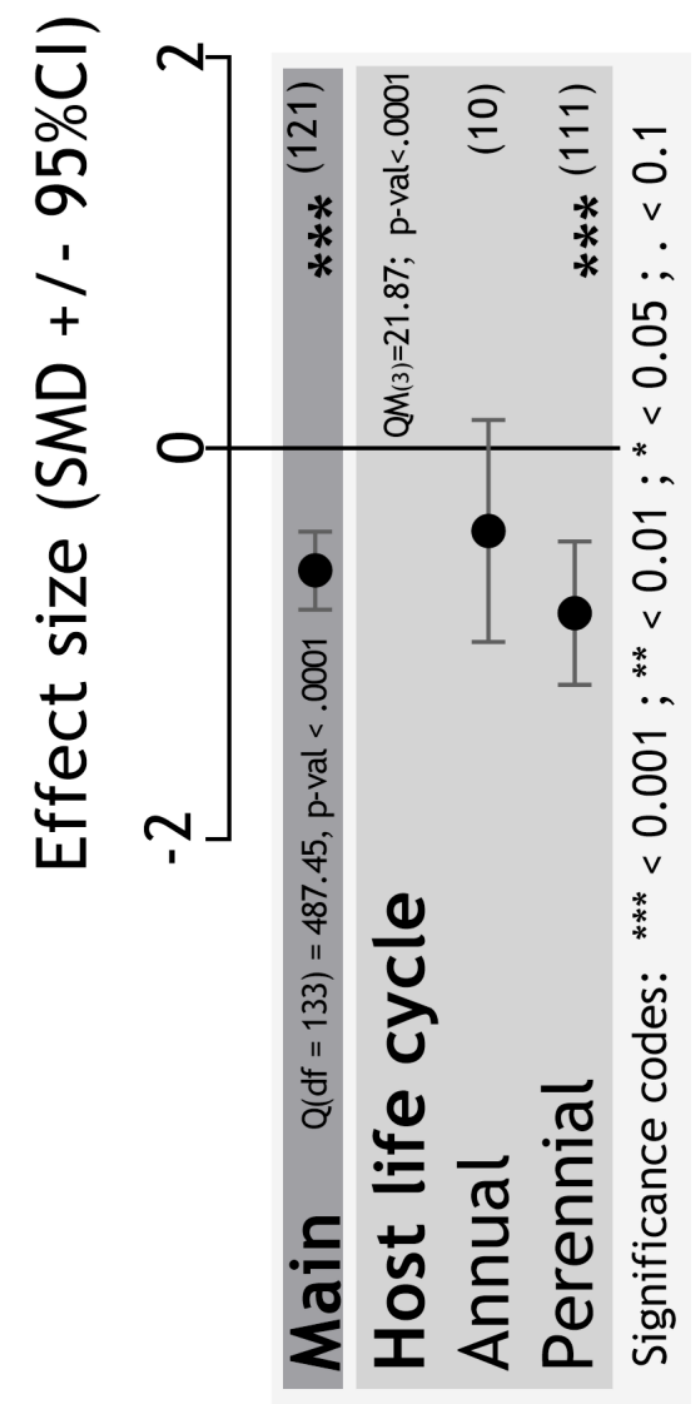




\section{Box 1. Glossary.}

Holobiont: Compound organism consisting of the macroscopic host together with all its symbiotic microorganisms (Rosenberg and Zilber-Rosenberg, 2014, Vandenkoornhuyse et al. 2015).

Microbiota: All microorganisms associated with a host (also called microbiome, Rosenberg and ZilberRosenberg, 2014).

Castrators: Fungal pathogens that reduce the fecundity of the plant by affecting the function of its reproductive organs with a negligible effect on vegetative organs (e.g., ergot, floral smuts, choke) (Burdon et al. 1993).

Killers: Fungal pathogens that cause rapid death of seedlings or mature plants (e.g., damping-off, root rots, wilts) (Burdon et al. 1993).

Debilitators: Fungal pathogens that cause discrete damage without an important impact on host fecundity/fitness (e.g. mildews, rusts, leaf necrotrophs)(Burdon et al. 1993).

Biotrophs: Fungal pathogens that obtain nutrients from living host tissues. Host immune responses are regulated by the salicylic acid-dependent pathway (Agrios, 1997, Glazebrook, 2005).

Necrotrophs: Fungal pathogens that derive nutrients from dead host tissues that they kill before or during colonization. Host immune response defense responses activated by jasmonic acid and ethylene signaling (Agrios, 1997, Glazebrook, 2005).

Hemi-biotrophs: Fungal pathogens that behave as both biotrophs and necrotrophs, depending on the environmental conditions or the stages of their life cycles (Agrios, 1997, Glazebrook, 2005).

Fungal Endophytes: Fungi that reside within plant tissues and cause no obvious disease symptoms during all or most of the host life cycle. Here, we reserved the term "fungal endophytes" to asexual Epichloë fungi of grasses.

Asexual Epichlö̈ endophytes: A group of Epichloë species previously classified in the genus Neotyphodium, that are symbionts of grasses that produce systemic and asymptomatic infections in aboveground organs of hosts (Class I endophytes, Rodriguez et al. 2009; Leutchmann et al., 2014). During the host reproductive stage, they colonize inflorescence primordia and developing ovules, being vertically transmitted to the next generation through host seeds (Clay and Schardl, 2002). Here, we refer to these endophytes as Epichloë fungal endophytes. 
Sexual Epichloë endophytes: Like the previous ones, they produce asymptomatic infections during the host vegetative growth phase. When the host enters its reproductive phase, the fungus also does it, producing a stroma that surrounds a plant reproductive stem, inhibiting the development of the plant inflorescence (Type I and II endophytes, Rodriguez et al. 2009). Perithecia formed in mature stromata will discharge fungal ascospores which might infect developing seeds of other plants, this the fungus is horizontally transmitted. Some sexual Epichloë species are not seed transmitted and develop stromata on most stems of their hosts. Here, we refer to these endophytes as sexual or pathogenic Epichlö̈ fungal endophytes. 